npalasic@ffri.hr

\title{
„Tko je lud u ovoj državi?!" Verbaliziranje emocija u političkom diskursu
}

\begin{abstract}
Palašić Nikolina, "Tko je lud u ovoj državi?" Verbaliziranje emocija u političkom diskursu ("Who is Crazy in this Country?" Verbalizing Emotions in Political Discourse). "Poznańskie Studia Slawistyczne" 9. Poznań 2015. Publishing House of the Poznań Society for the Advancement of the Arts and Sciences, pp. 65-76. ISSN 2084-3011.

In the center of our interest is the use of emotion-marked linguistic resources in the public discourse, and more specifically in the Croatian political public sphere. As politics is traditionally considered a place from which emotions should be expelled and where rationality is that characteristic which comes first in state administration, the question is where do political statements draw their emotional value and what is its role, i.e. if it occurs by accident or it is based on the speaker's intention. In this paper, we will try to answer those questions, taking into account previous reflections on emotions.
\end{abstract}

KeYwords: emotion; emotive communication; emotional communication; politics; affect

\section{Emocije iz znanstvene perspektive?!}

Još je Sigmund Freud istaknuo kako ,je nezgodno baviti se osjećajima iz znanstvene perspektive" (1994: 2). Dodajemo: još nezgodnije je iz znanstvene perspektive analizirati pojavu emocija u onom području društvenoga života koje bi se, barem prema tradicionalnom shvaćanju, trebalo bazirati na ratiu, a ne emotiu, konkretno u području politike. Istraživanje emocionalne komponente verbalnih izraza koje koriste političari može izazvati više pitanja negoli dati odgovora, no može i pridonijeti boljem razumijevanju načina na koji politika funkcionira. $U$ tom je smislu jedan od ciljeva ovoga rada tu povezanost emocionalnoga/emotivnoga ${ }^{1}$ i znanstvenoga učiniti manje, Freudovim riječima, nezgodnom.

${ }^{1}$ Emocije se obično smatraju spontanim reakcijama. No takva pojednostavljena tvrdnja treba dodatna pojašnjenja. Pored spontanih manifestacija emocija postoje i slučajevi kada se 
U ovome radu razmotrit će se uporaba i funkcija emotivnih izraza $\mathrm{u}$ izjavama odabranih hrvatskih političara, $\mathrm{i}$ to u njihovima svakodnevnim izjavama za javnost koje se odnose na određeni političko-društveni problem. Pritom se polazi zapravo od pretpostavke da su emocije fundamentalne u političkom životu, ali ne u smislu uzimanja prevlasti nad razumom, već u smislu postojanja emocionalne dimenzije u praksama koje čine politički diskurs. Da bi se opravdalo takvo polazište, potrebno je vratiti se i razmotriti kako se emocije objašnjavaju i definiraju u nekim dosadašnjim znanstvenim i, još uže, lingvističko-filozofskim istraživanjima.

Promišljanja o emotivnoj funkciji jezika u lingvističkim studijama mogu se u najmanju ruku pratiti još od vremena praške lingvističke škole. Brojni su pokušaji određenja jezičnih funkcija, a u jezikoslovlju su se ustalili Bühlerov (1934: 28) i Jakobsonov (1960: 353) jezični model, u kojima se naglašava komunikacijski karakter jezične uporabe. $\mathrm{O}$ emocijama se, osim u filozofiji jezika i lingvistici, puno raspravljalo (i raspravlja se) u brojnim znanostima (psihologiji, biologiji, antropologiji, socjologiji i dr.), a rezultati do kojih se dolazi ne podudaraju se uvijek. Novija istraživanja, posebice ona koja je uspostavio Antonio Damasio (2000), potvrđuju da ljudski unutrašnji svijet nije tek plošna povezanost ratia i emotia, već je zapravo riječ o kompleksnoj mreži funkcija i relacija poredanih $\mathrm{u}$ vremenske sljedove. Damasiov velik doprinos u istraživanju ljudskih emocija leži upravo u njegovu pokušaju dokazivanja činjenice da su razum i emocije nerazdvojne dimenzije ljudskoga bića. Razdvajanje razuma i emocija obično se u filozofiji jezika smatra Descartesovom pogreškom (zahvaljujući njegovu poznatom cogito, ergo sum), no kao što znamo, nakon Descartesa, odnosno od 17. st. naovamo, brojni su se znanstvenici bavili odnosom razuma i osjećaja te su i pokazali da emocije i te kako utječu na razum. Osim Damasiove tvrdnje o neodvojivosti ratia i emotia zanimljiv je i njegov stav da su emocije, baš kao i razum, ,biološki deter-

emocije strateški plasiraju. Takvo razlikovanje potječe još s početka 20. stoljeća, kada je Anton Marty (1908: 362) uveo razliku između emocionalne i emotivne komunikacije. Prema njegovu mišljenju, emocionalna je komunikacija spontano, nenamjerno korištenje emocija u govoru, dok se emotivna komunikacija usmjerava na utjecanje recipijentove interpretacije situacije. Ne postoji automatska ni nužna relacija prema govornikovu realnom afektivnom stanju, već postoji relacija prema autoprezentaciji, određenoj intenciji te takva uporaba jezičnih izraza ima persuasivni karakter. 
miniran proces" te da je posve pogrešno smatrati da je kultura ta koja ih u potpunosti oblikuje ${ }^{2}$.

Neki pak drugi autori, primjerice Barry Richards, bave se isključivo kulturološkom dimenzijom emocija. On polazi od činjenice da se ekspresija emocija događa unutar određenoga kulturološkog okruženja, pa stoga ne smijemo zanemariti ni društvenu uvjetovanost emocionalnih signala u komunikaciji. U tom smislu Richards (2007: 3-4) govori o trima razinama na kojima društvo upravlja emocijama. Na prvoj se nalaze kulturološki procesi svakodnevice, pri čemu se misli na načine na koje se odvijaju uobičajene komunikacijske razmjene među ljudima. Druga razina obuhvaća institucionalne strukture, i to od konstitucije države do upravljanja strukturama u organizacijama. Treća se odnosi na komunikaciju u javnoj sferi odnosno na sadržaj i stil poruka (političkih, komercijalnih, korporativnih) koje nas okružuju.

U ovom će radu biti riječ o trećoj Richardsovoj razini kulturološke podloge emocionalnih signala u komunikaciji, dakle onoj koja je najmanje ukorijenjena $u$ tu, nazovimo je, društvenu tvornicu, no ipak je vrlo potentna kada je riječ o upravljanju emocijama, naime radi se o razini komunikacije. Na neki nas način to vraća do prve Richardsove razine, one svakodnevnoga života, jer je komunikacija o kojoj je ovdje riječ ona koja nas okružuje u sferi medija, u javnoj komunikaciji, a ona uključuje i velik dio iskustava prosječne osobe s politikom. Razlika je pritom u tome što na toj prvoj razini govorimo o izravnoj interpersonalnoj interakciji i individualnom materijalu ili, Richardsovim riječima, „senzualnim iskustvima” poput kupovine, sporta i sl. Na trećoj razini posredovane komunikacije govorimo o zajedničkim iskustvima simboličke komunikacije proizvedene za javnu konzumaciju putem medija.

U političkom diskursu, odnosno u pojedinim isječcima komunikacije na političkoj sceni, u verbalnom izrazu može prevladavati bilo ekspresivna (emocionalna), bilo apelativna (emotivna) funkcija jezika. Pritom se svaka od tih dviju funkcija u jeziku može manifestirati implicitno i eksplicitno.

${ }^{2}$ Ipak, ne smijemo tvrditi da Damasio emocijama u komunikaciji u potpunosti odriče kulturološku uvjetovanost; on doduše tvrdi da su emocije biološki determinirane, no bez obzira na to okruženje i kultura imaju velik utjecaj na to kako će emocije u konačnici izgledati. Kultura, naime, oblikuje neke načine na koje će se emocije prezentirati te oblikuje kogniciju i ponašanje koje slijedi razvoj emocija (Damasio 2000: 57). Fokusiramo li se dakle, na uporabu jezika, na ono što ljudi čine s jezikom u dijaloškoj interakciji, moramo uzeti u obzir da je ona neizbježno pod utjecajem emocija. 
Implicitni je signal emocionalnosti tada sadržan u konotativnom dijelu jezičnoga znaka (u kontekstu ili kontekstu izrečenoga), a može se manifestirati na različite načine - od odnosa uspostavljenih u internim strukturama teksta, dakle među pojedinim tekstnim elementima, preko pripisivanja najvjerojatnijega značenja (konotacije) do kulturoloških obrazaca i prototipnih slika (cf. Winko 2003: 118) - dok je eksplicitni verbalni signal emocionalnosti sadržan u denotativnom značenju odabranih jezičnih jedinica (npr. „tužan sam”).

Stoga se može reći da je emotivna komunikacija intencionalna, da strateški signalizira afektivnu informaciju u govoru te se njome pokušava utjecati na način na koji će recipijent interpretirati situaciju, dakle usmjerena je cilju koji pošiljalac namjerava ostvariti. Emocionalna komunikacija smatra se spontanim, neintencionalnim propuštanjem emocija u komunikaciju. Time dolazimo do zaključka da emotivna komunikacija nema nužne realne povezanosti sa stvarnim emocionalnim stanjem pošiljaoca. Ona je u biti ciljana autoprezentacija, dakle inherentno je strateška, persuasivna, interakcijska i usmjerena prema drugome.

\section{Spojiti nespojivo - emocije i politika}

Demokratska vladavina uvijek je nužno ,vladavina putem jezika”. Utoliko ne začuđuje da općenito prevladava mišljenje kako jezik u politici - umjesto da služi komunikaciji između političara i ostalih građana - zapravo predstavlja instrument političko-strateških kalkulacija te služi umanjivanju sposobnosti donošenja realne prosudbe u potencijalnih birača (Sarcinelli 1987: 14). Hrvatska politička scena obiluje brojnim primjerima korištenja emotivnoga/emocionalnoga jezika ${ }^{3}$ u političkome diskursu

\footnotetext{
${ }^{3}$ Pod pojmom ,emotivni/emocionalni jezik” ovdje se misli na neki verbalni izraz koji u sebi sadrži indikator(e) emocija. Ovo nas određenje dovodi do potrebe za još jednim terminološkim razgraničenjem ili, bolje rečeno, pojašnjenjem. U postojećoj se literaturi (mahom na njemačkom i engleskom jeziku) često pronalazi nekonzistentna uporaba pojmova „emocije” i „osjećaji” (Emotionen i Gefühle; emotions i feelings). Takva je uporaba neke autore koji se u novije vrijeme bave emocionalnim ekspresijama na različitim razinama potaknula na eksplicitno pojašnjenje razlike između emocija i osjećaja. Dok se emocijama obično smatra čitav kompleks različitih stanja, koja uključuju osjećaje, psihičke promjene, razna ponašanja i impulse, zbog čega su povezane s mišljenjem i djelovanjem, osjećaji se nerijetko svode
} 
i upravo iznenađuje koliko je rijetko jezik hrvatskih političara predmet lingvističkih razmatranja i koliko se često pitanje verbalnoga stila nekog političara i primjerenosti njegovih izjava zadržava samo u okviru novinarskih komentara.

Nerijetko se u istraživanjima političkoga govora ciljano uzimaju primjeri iz predizborne kampanje, koji obiluju raznima manipulacijskim strategijama i eksplicitnim difamiranjima političkoga protivnika. No pritom u obzir treba uzeti i činjenicu da se nastupi u kampanjama uglavnom pomno pripremaju, a posebice je to slučaj kod političkih govora pred okupljenom publikom. No što je s govorom političara izvan predizborne kampanje? Možemo li izjave političara u razdoblju između dviju predizbornih kampanja smatrati spontanijima, pa u tom smislu i relevantnijima za istraživanje komunikacijskoga stila pojedinog političara?

Generalno gledajući, postoji određena tendencija na hrvatskoj političkoj sceni da se govor određenog političara mijenja nakon izbora, i to ne u smislu negiranja ili provedbe predizbornih programa, već u smislu odnosa prema javnosti ili, još konkretnije, prema novinarima koji mu postavljaju pitanja ili prema ostalim političarima s kojima ulazi bilo u izravan dijalog, bilo u dijalog posredovan medijima. Bez pripreme i autocenzure, upravo imanentnih govornicima u predizbornoj kampanji, govor političara nakon izbora češće je emocionalno obilježen, bez obzira na to imale te emocije pozitivan ili negativan predznak. Kako se kampanje, općenito uzevši, često uspoređuju s marketingom, promatrajući hrvatske političke prilike, upravo se nameće dojam da je nakon izbora reklamirani proizvod prodan kupcu, pa više i nema potrebe truditi se oko prodaje.

U političkom diskursu načelno vrijedi općenito vrlo oprezno doziranje emocionalno obojenih iskaza - izuzev kada je riječ o apeliranju na nacionalne osjećaje, što je u političkom diskursu legitimno i upravo poželjno - jer postoji bojazan da bi se velikom uporabom emotivnih izraza mogla izazvati sumnja u vjerodostojnost kao i zaraditi etiketa iracionalnosti, pa čak i emocionalne labilnosti. S druge pak strane političar mora pokazivati humanost i ne smije se prezentirati kao osoba posve lišena emocija

na fizičke osjete (cf. Wierzbicka 1999: 2). Za potrebe ovoga rada koristit će se dakle, izrazi „emocija, emocionalno, emotivno”, uz već ranije navedenu razliku između „emotivnoga” i ,emocionalnoga”. 
jer takve osobe načelno nisu poželjne u društvu, pa tako ni u političkom vodstvu, no ta se emocionalnost uglavnom svodi na sposobnost empatije (Schaal, Heidenreich 2013: 3).

Hrvatska je politička scena specifična i zbog svoje ne tako davne prošlosti odnosno činjenice da od devedesetih godina, kada se u političkome vrhu uspostavio kult vođe, u najvećem dijelu društva tinja potreba za snažnom liderskom osobnošću (tj. za politikom čvrste ruke), pa je u tom smislu još više izražena nepodobnost emotivnih izjava, koje izazivaju podsmijeh, a posebice ako dolaze od žene ${ }^{4}$. O nezavidnoj ulozi žene na političkoj poziciji, koja, tradicionalno, zahtijeva racionalnost u društveno-politički relevantnom odlučivanju, može se argumentirati i iz pozicije liberalističkoga dualizma, gdje se ratio i emotio odvajaju, pri čemu konotacije racionalnoga pripadaju muškarcima, a konotacije emocionalnoga ženama. Taj je dualizam liberalne tradicije već neko vrijeme predmet i brojnih feminističkih kritika, koje ukazuju upravo na tendenciju isključivanja s emocijama povezivih osoba iz političke debate odnosno na sklonost umanjivanju njihovih racionalnih sposobnosti (Schaal, Hedienrecih 2013: 6). Kao što smo već spomenuli, hrvatska je politička situacija od devedesetih naovamo specifična, a tomu pridonosi i činjenica da se hrvatski politički sustav može načelno definirati kao liberalizam, no u njemu ima još mnogo dodirnih točaka s drukčijim, autokraciji orijentiranim sustavima ${ }^{5}$, poput snažne naglašenosti nacionalne komponente, nefleksibilnosti tržišta te odricanja temeljnih ljudskih prava pojedinim manjinama. Osim toga hrvatsko je

\footnotetext{
${ }^{4}$ Pritom se misli na premijerski mandat Jadranke Kosor, čije su se izjave uvijek interpretirale s obzirom na njezin rodni identitet $\mathrm{i}$ često su danima bile predmet podrugljivih komentara, a neke od njih stvorile su i nove asocijacije u hrvatskome društvu (primjerice malotko na spomen krumpir-salate neće pomisliti na Kosor zahvaljujući njezinoj izjavi da je od premijera koji je dao ostavku preuzela vruć krumpir, no da to nije problem jer će ona u ženskom stilu od njega napraviti finu krumpir-salatu). Za razliku od izjava Jadranke Kosor izjave njezinih muških političkih kolega, u nespretnosti i, eventualno, neprimjerenosti posve ravnopravne njezinima, nisu se uzimale s tolikim zanimanjem, odnosno mediji ih nikada nisu prikazivali kao nešto što bi trebalo posebno izdvojiti niti se time posebno baviti.

${ }^{5}$ Lalović (2001: 21) suvremeno hrvatsko društvo opisuje kao konstrukt koji karakteriziraju ,strukturni rascjepi i simbolički raskoli hrvatskoga društva, neizgrađen stranački sustav, polarizirani stranački pluralizam, prenaglašena politička uloga vojnoga i policijskog aparata", a sve te karakteristike ne možemo svrstati među oznake liberalizma, već upravo suprotno, među oznake autokratskoga režima.
} 
društvo u najvećem svom dijelu izrazito konzervativno i patrijarhalno, što jasno implicira kakva je u njemu onda pozicija žene.

U takvim se zadanostima emocionalni izrazi na političkoj sceni povezuju sa znakovima slabosti, ali opet samo ako je riječ o emocijama s, uvjetno rečeno, pozitivnim predznakom (npr. ganuće). Emocije koje ukazuju na negodovanje, ljutnju ili uvrijeđenost ne promatraju se iz iste perspektive - one se, upravo suprotno, povezuju sa snagom karaktera, a ne s njegovom slabošću.

U nastavku slijedi analiza emocionalnoga udjela u komunikaciji na aktualnoj hrvatskoj političkoj sceni te će se pokušati odrediti jesu li manifestacije emocija u jeziku u analiziranim primjerima više emocionalnoga ili emotivnog karaktera i je li na temelju dobivenih podataka moguće izvesti kakav općenit zaključak o načinu na koji se emocije realiziraju u hrvatskom javnom političkom diskursu.

\section{3. „Kojim pravom od mene pravite budalu?!”}

Ovaj podnaslov, upravo kao i naslov cijeloga rada („Tko je lud u ovoj državi?!"), najava je razmatranja upotrebe emocionalnih i emotivnih verbalnih izraza na nekoliko primjera s aktualne hrvatske političke scene. Pitanje „Tko je lud u ovoj državi?!” postavio je hrvatski ministar financija Slavko Linić u intervjuu za „Media servis” komentirajući kritike koje je Obrtnička komora uputila Poreznoj upravi i dodajući: „Ja zaista imam posla sa sve više luđaka. To nisu normalni razgovori. Ja zbilja ne mogu k sebi doći, ne mogu k sebi doći" (<http://www.vecernji.hr/hrvatska/linicja-zaista-imam-posla-sa-sve-vise-ludjaka-622103>, 14.03.2014).

U kontekstu ranije navedenoga možemo vidjeti da je $\mathrm{u}$ ovome kratkom isječku političkoga intervjua riječ o eksplicitnoj emocionalno-emotivnoj uporabi jezičnih izraza. Leksemi poput „lud” i „luđak” već u samom svome značenju imaju negativnu komponentu, a upotrijebljeni u ovakvom kontekstu (retoričko pitanje eksklamativnog karaktera u prvom i bespomoćan zaključak u drugom slučaju) jasno upućuju na emocionalno stanje govornika odnosno na njegovu iritiranost. Tu ne može biti riječi o emotivnoj uporabi jezika u smislu promišljena plasiranja izjava sa zadanim persuasivnim ciljem (cf. npr. Marty 1908), već se zapravo radi o verbalizaciji govornikova emocionalnog stanja, pri čemu ta verbalizacija, u ovom slučaju, 
može utjecati na kreiranje stava ili promjenu mišljenja u recipijenta, iako joj to nije bio (primarni) cilj.

Verbalizacija govornikovih emocija je implicitno i eksplicitno prezentirana u primjeru „Ja zbilja ne mogu k sebi doći”. Implicitni pokazatelj emocija sadržan je u načinu na koji su povezani dijelovi teksta (ponavljanje cijele rečenice) te u modalnom izrazu ,zbilja”, kojim se naglašava stav govornika prema izrečenome, a eksplicitnost ove emocionalne izjave vidljiva je iz samoga značenja te upućuje na emocije koje uključuju čuđenje i negodovanje.

Sljedeći primjer verbaliziranja emocija potječe od istoga političara, a odnosi se na njegovu reakciju na novinarski upit zašto toga dana u Saboru nije sjedio na svome mjestu. Vidno iritiran, izjavio je: „Za vas je to interesantno, ali za mene je to toliko notorna glupost da me vrijeđate, vrijeđate me. Pa kojim pravom od mene pravite budalu?" $(<$ http://danas.net.hr/ hrvatska/linic-izgubio-zivce-i-izvrijedjao-novinarku-htv-a>, 14.03.2014).

Kako vidimo, ponovno je riječ o emocionalnoj verbalizaciji, točnije o afektu. Govornik ovdje upravo tematizira vlastite emocije te naglašava (i ponavlja) da je pritom riječ o uvrijeđenosti. Osim toga na vrlo jasan način ukazuje na svoju poziciju (nad)moći u odnosu prema novinarima, i to na dva načina: prvo minorizira njihovu inteligenciju ukazujući na to kako ih zabavljaju, prema njegovu mišljenju, besmislice, a zatim ih retoričkim pitanjem upozorava na to da nemaju pravo obraćati mu se na taj način. Emocionalnost se, osim u ukupnom značenju citirane izjave, ogleda već i u denotativnom značenju leksema ,glupost”, pojačanog atribucijom ,notorna”, ,vrijeđati” i invektivom „,budala”.

Za razliku od prvih dvaju primjera, gdje se emocionalnost u jeziku manifestira kao već ranije spomenuto neplanirano propuštanje emocija u govor, sljedeći nam primjer pokazuje implicitnu i intencionalnu verbalizaciju emocija: „Premijer odrađuje zahtjevan posao i u interesu građana je da bude smiren i ne želim ga dodatno uzrujavati" (<http://www.tportal.hr/ vijesti/hrvatska/322944/Holy-otkrila-sto-joj-je-Milanovic-nudio.html>, 23.03.2014). Ova izjava Mirele Holy, osnivačice i predsjednice nove hrvatske stranke OraH, odabrana je upravo iz razloga što je emocionalna komponenta u njoj toliko implicitna da je gotovo neprepoznatljiva. Priopćenja ovakva tipa možda najbolje pokazuju razliku između emocionalne i emotivne uporabe jezika. Ovdje je naime, riječ o emotivnoj verbalizaciji 
pošiljaočeva stava prema drugoj osobi, gdje se vrlo suptilnom ironijom ukazuje na njezinu nesposobnost svladavanja kompleksnih zadaća. Iako se eksplicitno upućuje na to da ta osoba ima zahtjevnu zadaću, u podtekstu se nalazi informacija da je ta zadaća za nju prezahtjevna te da joj treba osigurati potpun mir jer bi svako uznemiravanje moglo rezultirati nekim premijerovim potezom koji bi bio loš za cijeli narod. Ovakvom se objavom u recipijenta želi stvoriti točno određeno mišljenje o osobi o kojoj se govori, a ovdje je konkretno riječ o nedostatku sposobnosti potrebnih za vođenje države. Kako se iskazi evaluativnog tipa baziraju na emocionalnoj podlozi, ukoliko se može dokazati da njihov autor stoji u nekoj individualnoj relaciji prema onome što evaluira (Jahr 2000 :12), kao u ovom slučaju možemo na temelju poznavanja relacija između pošiljaoca gore navedene izjave i osobe o kojoj govori zaključiti da je riječ i o emotivnom, a ne samo kognitivnom evaluativnom iskazu.

U svrhu potkrepljivanja gore u tekstu iskazanih promišljanja o poziciji žene na hrvatskoj političkoj sceni donosimo ovdje prošlogodišnje priopćenje hrvatskoga premijera Zorana Milanovića koje, osim što ukazuje na nezavidan položaj žene u društvu i politici, sadrži i eksplicitnu tematizaciju emocije: „Izborite se, budite pametnije, inteligentnije i lukavije i zaboravit će da ste žene, bojat će vas se!" (<http://vijesti.hrt.hr/budite-pametnijei-zaboravit-ce-da-ste-zene>, 16.02.2014). Ovdje je opet riječ o emotivnoj uporabi jezika, pri čemu se tematizira emocija straha. Kao što smo već ranije naveli, emocije koje imaju negativan predznak ili ukazuju na grubosti u hrvatskoj politici su ne samo prihvatljive nego i poželjne, što vrlo jasno vidimo u ovom primjeru, gdje se ženama savjetuje što sve trebaju promijeniti da bi izazvale emociju straha odnosno da bi bile uspješne u politici.

Emocionalnost je, za razliku od emotivnosti, vrlo jasno vidljiva u iskazima izrečenim u afektu, a takvih je u hrvatskome političkom diskursu nebrojeno mnogo zahvaljujući već gore navedenoj činjenici da se grubost i agresivnost ne smatraju nužno negativnim pojavama, pa se onda emocionalni aspekt političkoga jezika nerijetko ogleda u eksplicitnim uvredama, kao što je primjerice slučaj u izjavi sindikalnog čelnika Ribića: „Linićeva izjava kretenska je da ne može biti kretenskija, a potrebna mu je kao obrazloženje za one u stranci koji imaju koeficijent inteligencije manji od 80" (<http://www.vecernji.hr/ribic-tuzi-ministra-linica-zbog-kretenske-izjave-557417>, 16.02.2014, istaknula N.P.). Govornikom u trenutku 
takve izjave vlada emocija ljutnje, a možda i uvrijeđenosti, što onda izaziva ovakvo eksplicitno korištenje emocionalnih izraza.

Naravno, vrijeđanje može biti izgovoreno i u planiranim iskazima, dakle preduvjet mu nije nužno afekt, kao što je slučaj u sljedećem primjeru: „Ruža Tomašić gora je od elementarne nepogode... to je za mene društvena nepogoda" (<http://www.vecernji.hr/hrvatska/milanovic-ruza-tomasic-gora-jeod-elementarne-nepogode-539476>, 16.2.2014; istaknula N.P.).

Uspoređivanje osobe s elementarnom nepogodom ukazuje na njezinu destruktivnu prirodu, čime se ciljano pokušavaju izazvati negativne emocije u recipijenta. U tom je smislu ovdje riječ o emotivnoj uporabi verbalnih sredstava, koja može, ali i ne mora, počivati na nekoj emociji u pošiljaoca.

\section{O emocijama zaključno}

U prethodnome poglavlju provedena analiza daje naslutiti ne samo da za hrvatski korpus ne vrijedi sasvim tvrdnja da se emocionalno obojeni iskazi oprezno doziraju u političkom diskursu (cf. Schaal, Heidenreich 2013: 2) već i da je na hrvatskoj političkoj sceni situacija gotovo obrnuta naime nije iziskivalo posebna truda pronaći korpus za ovaj rad: emocionalne i emotivne komponente iskaza upravo je teško mimoići (a ne pronaći!) u izjavama za javnost hrvatskih političara.

Dakako, ovdje je zbog obima rada navedeno samo nekoliko primjera, no odabrani su tako da obnašaju funkciju prototipnih predstavnika načina na koji se emocije verbaliziraju u hrvatskome javnopolitičkom diskursu. Iako se u literaturi obično razlikuju emotivni od emocionalnih iskaza, u praksi se češće pronalaze primjeri koji u manjoj ili većoj mjeri sadržavaju obje komponente. Možemo reći da se verbaliziranje emocija u ovdje analiziranu korpusu odvija na skali čije su krajnje točke emotivna i emocionalna verbalizacija, pa se ovdje analizirane izjave u tom kontekstu kreću od izrazito emotivnih do izrazito emocionalnih.

Kao što je u uvodnome dijelu navedeno, u korpusu je teško pronaći emotivne i emocionalne izraze kojima bi se tematizirale pozitivne emocije jer bi se takvo verbaliziranje emocija s jedne strane smatralo slabošću, a s druge strane postoji mišljenje da takvim iskazima nije mjesto u politici (npr. „ganulo me”, „razveselilo me”, „usrećilo me” i sl.). Takve se emocije 
mogu pronaći kada je riječ o nacionalnim osjećajima, a u ovom slučaju posebice ako su vezani i uz Domovinski rat jer vlada neizrečeno mišljenje da u tom slučaju nipošto nije riječ o slabosti, primjerice: „Osjećam da su nam se vratili ona energija i emocije s početka devedesetih. Osjećam da su Bog i hrvatski narod ponovno uz HDZ, a čujem i onih 15000 mrtvih prijatelja iz Domovinskog rata..." (<http://www.slobodnadalmacija.hr/Dalmacija/ Splitzupanija/tabid/76/articleType/ArticleView/articleId/237084/Default. $\operatorname{aspx}>, 16.04 .2014$.$) .$

Nedostatak, uvjetno rečeno, pozitivnih emocija nadoknađuje druga krajnost - naime osim eksplicitnih pozitivnih emocionalnih izraza nisu česti ni implicitni (negativni) emotivni izrazi poput onoga Mirele Holy. Najčešći su slučaj verbaliziranja emocija u hrvatskome političkom diskursu zapravo eksplicitne uvrede. Pored u analizi navedenih primjera susrećemo se s još nizom takvih izjava, koje možemo svrstati u nekoliko kategorija, ovisno o tome koji je leksem nosilac negativnih asocijacija: nesposobnost - „Ova vlada ne zna, nesposobna je i točka!” (Jurčić o Vladi RH); laganje - „Ja vam uzvraćam istom mjerom i javno vam kažem da namjerno lažete” (Lesarov odgovor Mrsiću); „Kad bi Mrsić bio Pinokio, nos bi mu bio do zadnjeg koji sjedi u sabornici. Ne može ni Pinokiju narasti toliko nos koliko Mrsić može lagati” (sindikalni čelnici o Mrsiću); kriminal+nesposobnost - „SDP je nesposoban, a u HDZ-u su lopovi i kriminalci” (Šišljagić o HDZ-u i SDP-u); nedostatak razuma - „Oni su u potpunom deliriju (Karamarko o SDP-u); psihička bolest - Kad se hvale da su najbolja vlada u hrvatskoj povijesti, onda je to znak da im treba kolektivna psihoterapija" (Karamarko na skupu u Omišu); silovanje - „I dok jedni siluju naš mentalni sklop, dok siluju naše nacionalno biće, gospodin na drugome brdu perfidno radi protiv interesa vlastitoga naroda" (Karamarko o Josipoviću); četnici - „Neće nama četnički vojvode pregledavati naše udžbenike” (Karamarko o Jovanoviću) i sl. Cilj je ovakvih izjava, kada je riječ o emotivnoj uporabi jezika, difamiranje osobe ili stranke na vrlo eksplicitan način, a kada je riječ o emocionalnoj uporabi, onda je ona odraz negativnih emocija, što opet i u recipijenata stvara negativnu sliku o osobi ili stranci o kojoj je riječ.

Dakle kao što smo na početku ovoga rada i pretpostavili, bavljenje emocijama iz znanstvene perspektive nije jednostavan pothvat, a navedeni primjeri potvrđuju da unatoč u postojećoj literaturi nerijetko jasnom teorijskom razgraničenju, nije uvijek moguće jasno razgraničiti emocionalnu 
i emotivnu uporabu jezika, jer s jedne strane neki emocionalni izraz često može polučiti (za pošiljaoca doduše možebitno poželjan, ali ne nužno i namjeravan) efekt kod recipijenta, a s druge strane ne možemo sa sigurnošću tvrditi da se neka emotivna verbalizacija ne bazira ujedno i na emocionalnoj podlozi, iako ona $\mathrm{u}$ danom primjeru nije tematizirana. $\mathrm{O}$ tome trebamo li neki izraz tumačiti kao emotivan ili emocionalan možemo zaključiti jedino iz svoga općeg znanja i poznavanja određene kulture i društva, dakle onda i govornika koji mu pripadaju. Jedino tako možemo znati je li pojedinom slučaju neki političar više sklon ne baš promišljenim verbalnim ispadima ili pak pomno razmišlja o onome što će reći i ciljano dozira signale emocija u svoj govor. No kriteriji na temelju kojih to možemo zaključiti nisu nužno znanstveni, već, kako rekosmo, kulturološki. Na kraju se može reći da proučavanje emocionalnoga aspekta jezika iz lingvističke perspektive doista otvara uvijek nova pitanja te $u$ analizi zahtijeva uključivanje i drugih aspekata.

\section{Literatura}

Bühler K., 1934, Sprachtheorie. Die Darstellungsfunktion der Sprache, Jena.

Damasio A., 2000, The Feeling of What Happens. Body, emotion and the making of consciousness, London.

Freud S., 1994, Das Unbehagen in der Kultur, Frankfurt am Main.

Jahr S., 2000, Emotionen und Emotionsstrukturen in Sachtexten, Berlin.

Jakobson R., 1960, On language, ur. L.R. Waugh, M. Monville-Burston, Cambridge.

Laabs H.J. (ur.), 1987, Pädagogisches Wörterbuch, Berlin.

Lalović D., 2001, Politički pluralizam i ustavnopravni status političkih stranaka, „Politička misao" br. 4, str. 21-32.

Marty A., 1908, Untersuchungen zur Grundlegung der allgemeinen Grammatik und Sprachphilosophie, Halle.

Richards B., 2007, Emotional Governance. Politics, Media and Terror, New York.

Sarcinelli U. (ur.), 1987, Politikvermittlung. Beiträge zur politischen Kommunikationskultur, Bonn.

Schaal G.S., Heidenreich F., 2013, Zur Rolle von Emotionen in der Demokratie, „Aus Politik und Zeitgeschichte. Politik und Emotionen" br. 32/33, str. 3-11.

Wierzbicka A., 1999, Emotions Across Languages and Cultures: Diversity and Universals, Cambridge.

Winko S., 2003, Kodierte Gefühle. Zu einer Poetik der Emotionen in lyrischen und poetologischen Texten um 1900, Berlin. 